\title{
Cancer as a Ciliopathy: The Primary Cilium as a New Therapeutic Target
}

\section{Castresana JS*}

Department of Biochemistry and Genetics, University of Navarra School of Sciences, Pamplona, Spain

*Corresponding author: Castresana JS, Professor of Genetics, Department of Biochemistry and Genetics, University of Navarra School of Sciences, Irunlarrea 131008, Pamplona, Spain, Tel: +34-948-425600 (ext. 806486); Fax: +34.948.425740; E-mail: jscastresana@unav.es

Received date: December 26, 2015; Accepted date: December 29, 2015; Published date: December 30, 2015

Copyright: ( 2015 , Castresana JS. This is an open-access article distributed under the terms of the Creative Commons Attribution License, which permits unrestricted use, distribution, and reproduction in any medium, provided the original author and source are credited.

Keywords: Primary cilium, Sonic hedgehog pathway, PTCH, SMO, related to cell differentiation and signaling. The study of primary cilia GLI has nowadays become of impact, both in terms of developmental biology, within ciliopathies [1], and in cancer [2]. In this sense the cilium is understood as an anchor cellular structure for molecules that

\section{Introduction}

\section{The primary cilium versus motile cilia}

Research on primary cilium is taking an increasing interest, both for scientists engaged in developmental biology, and for those dedicated to cancer research. Decades ago, the primary cilium was considered to be a vestigial organ of embryonic development. Its structure is different from that of motile cilia. The latter present a structure of 9 pairs of microtubules plus 2 central microtubules; primary cilia only consist of 9 pairs of microtubules. Primary cilia modulate several functions are processed into it, being transported up and down the cilium by kinesin and dynein proteins.

\section{Sonic hedgehog: a molecular pathway linked to the primary cilium}

In this respect, the sonic hedgehog (Hh) pathway has been documented to be related to primary cilia [2]. Before taking into account the function of primary cilia in cancer development, we will summarize the regulation of the Hh pathway (Table 1).

\begin{tabular}{|c|c|c|c|c|c|c|c|c|}
\hline & \multicolumn{4}{|c|}{ Primary cilium is present: correct ciliogenesis } & \multicolumn{4}{|c|}{ Absence of primary cilium: incorrect ciliogenesis } \\
\hline & $\begin{array}{l}\text { Will GliA be produced in } \\
\text { the cilium? }\end{array}$ & $\begin{array}{l}\text { Gli target } \\
\text { genes }\end{array}$ & Cell growth & Therapy & $\begin{array}{l}\text { Will GliA be produced in } \\
\text { the cilium? }\end{array}$ & $\begin{array}{l}\text { Gli } \\
\text { target } \\
\text { genes }\end{array}$ & Cell growth & Therapy \\
\hline $\begin{array}{l}\text { ligand } \\
\text { overexpression } \\
\text { (SHH, DHH, IHH) }\end{array}$ & YES & ON & increased & robotnikinin & NO & OFF & Not increased & Not required \\
\hline $\begin{array}{l}\text { SMO activating } \\
\text { mutations }\end{array}$ & YES & ON & increased & $\begin{array}{l}\text { cyclopamine } \\
\text { vismodegib }\end{array}$ & NO & OFF & Not increased & Not required \\
\hline $\begin{array}{l}\text { PTCH inactivating } \\
\text { mutations }\end{array}$ & YES & ON & increased & $\begin{array}{l}\text { cyclopamine } \\
\text { vismodegib }\end{array}$ & NO & OFF & Not increased & Not required \\
\hline $\begin{array}{l}\text { Gli1 gene } \\
\text { amplification }\end{array}$ & $\begin{array}{l}\text { NOT, but Gli1 proteins } \\
\text { overexpressed from Gli1 } \\
\text { gene amplification will } \\
\text { be the GliA forms }\end{array}$ & ON & increased & GANT & $\begin{array}{l}\text { NO, but Gli1 proteins } \\
\text { overexpressed from Gli1 } \\
\text { gene amplification will } \\
\text { be }\end{array}$ & ON & increased & GANT \\
\hline
\end{tabular}

Table 1: Hh pathway regulation in two different conditions (with and without primary cilium): implications for specific treatments.

The most important molecules to be considered within the $\mathrm{Hh}$ pathway are the Hh ligands ( $\mathrm{SHH}, \mathrm{DHH}$ and $\mathrm{IHH}$; for Sonic, Desert and Indian Hedgehog, respectively), $\mathrm{PTCH}$ ligand receptor (a transmembrane receptor that acts as a tumor suppressor gene), the SMO receptor (a $G$ protein-coupled receptor that acts as an oncogene), and the Gli proteins $(1,2$, and 3), of which 1 and 2 are considered to act as GliA (Gli activator proteins), while Gli3 is the main Gli repressor (GliR).

Trying to illustrate the regulatory mechanisms of the Hh pathway, we may say the following: PTCH inhibits SMO when PTCH is free of its ligand ( $\mathrm{SHH}, \mathrm{DHH}$ or $\mathrm{IHH})$. Ligand binding to $\mathrm{PTCH}$ releases the inhibition of PTCH on SMO, leaving SMO in an active form to induce Gli activation, and thus make active Gli induce the expression of its downstream target genes, such as cyclins, MYC, PTCH, etc. Hh in a hyperactive status will induce cell growth and cancer development.

SHH, SMO and GLI behave as oncogenic products, as they lead to cell cycle activation. On the contrary PTCH acts as a tumor suppressor gene, as it inhibits SMO. Inactivating mutations in $\mathrm{PTCH}$, or activating mutations in SMO contribute to $\mathrm{Hh}$ activation and cell growth promotion. GLI1 gene amplification and ligand overexpression are the other two typical alterations that would enhance Hh activity.

But this description of the regulation of the Hh pathway will not be sufficient to understand the whole picture, unless we count with the role of the primary cilium to better explain $\mathrm{Hh}$ regulation [2]. When SMO gets active, after ligand binding to $\mathrm{PTCH}, \mathrm{SMO}$ moves to the cilium, where it can execute its function: production of Gli active 
forms (GliA), mainly Gli2. If the primary cilium is not present, SMO can do nothing to produce GliA. The cilium is required for SMO to form GliA and have Hh activated to promote cell growth. So, we might say that an active SMO plus the presence of a primary cilium will produce GliA and Hh activation, while the contrary is usually true as well: an active SMO without a primary cilium will not produce GliA, so Hh will get inactive. There is one exception to this second rule: the presence of GLI1 gene amplification. In this context, a major proportion of GliA overexpressed from the GLI1 amplified gene (and not produced by SMO activity in the cilium, as there is no cilium) versus that of GliR existing in the cytoplasm will produce $\mathrm{Hh}$ activation.

In summary, we might almost take as a rule the next statements (Table 1): first, the presence of primary cilium associates to cancer formation if any or several of the next alterations are present: Hh ligand overexpression, $\mathrm{PTCH}$ inactivating mutations, or SMO activating mutations; second, the absence of cilium lead us to think that no cancer is going to be produced by activation of the Hh pathway by any or several of the alterations already referred above; and third, the exception to this rule would be the absence of primary cilium together with Gli1 gene amplification, a common molecular alteration in gliomas [3]: in such a condition, Gli overexpression of GliA forms would be produced without requiring the presence of the primary cilium; therefore we would have a Hh-linked cancer in cells that do not have a primary cilium.

All these conditions would require different specific therapeutic approaches [2]. It is well known that cyclopamine and vismodegib are active SMO inhibitors, while robotnikinin is an inhibitor of $\mathrm{Hh}$ ligands, and GANTs are inhibitors of GliA forms. A tumor presenting primary cilia and $\mathrm{Hh}$ activation by $\mathrm{Hh}$ ligand overexpression, $\mathrm{PTCH}$ mutations, or SMO mutations, should be specifically treated according to the lesion presented. But it is remarkably important to underline that this would not be true if primary cilia were not present; in such a case no treatment targeting the Hh pathway would be required against Hh ligand overexpression, PTCH mutations, or SMO mutations, as none of those three alterations or any combinations of them would be able to increase cell growth in cells without primary cilia required for GliA production. Only the exceptional case of cells without primary cilia and with Glil gene amplification should be treated with GANTs and with no other of the described specific treatments for each specific lesion of the Hh pathway.

\section{Is the primary cilium a cancer repressor or a cancer promoter?}

The association between cancer and presence of primary cilium is not as straightforward as it seems at first sight. There is a line of scientific thinking that defends that cilia might repress tumor formation. One example is the VHL tumor suppressor gene, that seems to maintain cilia $[4,5]$. Therefore VHL mutations, producing Von Hipple Lindau disease, an inherited condition whose patients suffer from renal cell carcinoma, would reduce cilia; truly, cells of the renal premalignant cysts of VHL disease lack cilia.

We can see a second example in the articles published by Mooser et al., [6,7], where they demonstrate by electron microscopy that glioblastoma cells and tumors do not present primary cilia, and they even propose that primary ciliogenesis is disrupted at an early stage in glioblastoma, maybe involving protein Cap123.
Thirdly, Sarkisian et al., [8] give some clues on the molecular aspects of ciliogenesis by demonstrating that protein CCRK, a positive regulator of the cell cycle, is abnormally high in cells that lack primary cilia (U251 glioblastoma cell line), and that knockdown of CCRK in U251 cells induced ciliogenesis and inhibited U251 proliferation, which seems to demonstrate that cilia might repress tumor formation.

On the other side, some studies make us think that the presence of cilia is required for cancer development. Sarkisian et al., [8] saw primary cilia in glioblastoma cells and tumors, but only in those cells which are more proliferative, more invasive and resistant to chemotherapy. Secondly, knowing that Kif3A is a protein required for ciliogenesis, it has been demonstrated that Kif3A knockdown inhibits cilia and inhibits medulloblastoma and basal cell carcinoma growth [9-11]. Thirdly, Emoto et al., [12] could determine the presence of cilia in $25 \%$ of pancreatic ductal carcinoma tumor samples, just the tumors associated to worse prognosis.

These three last papers show that at least a part of the cells that constitute the tumor mass might have cilia. Even, those ciliated cells seem to be prognostically worse. More studies should be done in this respect, in order to separate populations of cancer cells with and without cilia, and see the differences between them. The ciliacontaining cells might be associated to the cancer stem cell (CSC) phenotype, as CSC show an increase of proliferation, migration and resistance to chemotherapy, as the ciliated tumor cells of some publications seem to show $[8,12]$.

Whether ciliated cancer cells associate to CSC or not, is something so far undetermined, and requires further research at the morphological and molecular levels of the primary cilium, to help doctors establish a better clinical prognosis and treatment for the patients. A second interesting question regarding cilia research might concern the various different molecular pathways (not just Hh) that might depend on cilia to execute their functions $[13,14]$. Finally, an ample study on tumors derived from the different blastodermic layers, including carcinomas, sarcomas, leukemia-lymphoma, neuroectodermal tumors, and those derived from the neural crest (both from ectoderm and mesectoderm), would be very beneficial to evaluate the role of the primary cilium along many different tumors of different origin and with different mutations; a question of high importance to test the hypothesis of cancer as a ciliopathy.

\section{Acknowledgement}

This research was supported in part by grants from the Departmento de Salud del Gobierno de Navarra, Caja Navarra (project 13912), Fundación Universitaria de Navarra, Pamplona; and Fondo de Investigación Sanitaria (PI081849), Madrid.

\section{References}

1. Cortes CR, Metzis V, Wicking C (2015) Unmasking the ciliopathies: craniofacial defects and the primary cilium. Wiley Interdiscip Rev Dev Biol 4: 637-653.

2. Hassounah NB, Bunch TA, McDermott KM (2012) Molecular pathways: the role of primary cilia in cancer progression and therapeutics with a focus on Hedgehog signalling. Clin Cancer Res 18: 2429-2435.

3. Rao SK, Edwards J, Joshi AD, Siu IM, Riggins GJ (2010) A survey of glioblastoma genomic amplifications and deletions. J Neurooncol 96: 169-179.

4. Thoma CR, Frew IJ, Krek W (2007) The VHL tumor suppressor: riding tandem with GSK3beta in primary cilium maintenance. Cell Cycle 6: 1809-1813. 
Citation: Castresana JS (2015) Cancer as a Ciliopathy: The Primary Cilium as a New Therapeutic Target. J Carcinog Mutagene 6: e119. doi:

Page 3 of 3

5. Plotnikova OV, Golemis EA, Pugacheva EN (2008) Cell cycle-dependent ciliogenesis and cancer. Cancer Res 68: 2058-2061.

6. Moser JJ, Fritzler MJ, Rattner JB (2009) Primary ciliogenesis defects are associated with human astrocytoma/glioblastoma cells. BMC Cancer 9: 448.

7. Moser JJ, Fritzler MJ, Rattner JB (2014) Ultrastructural characterization of primary cilia in pathologically characterized human glioblastoma multiforme (GBM) tumors. BMC Clin Pathol 14: 40.

8. Sarkisian MR, Siebzehnrubl D, Hoang-Minh L, Deleyrolle L, Silver DJ, et al. (2014) Detection of primary cilia in human glioblastoma. J Neurooncol 117: 15-24.

9. Barakat MT, Humke EW, Scott MP (2013) Kif3a is necessary for initiation and maintenance of medulloblastoma. Carcinogenesis 34: 1382-1392.

10. Han YG, Kim HJ, Dlugosz AA, Ellison DW, Gilbertson RJ, et al. (2009) Dual and opposing roles of primary cilia in medulloblastoma development. Nat Med 15: 1062-1065.
11. Wong SY, Seol AD, So PL, Ermilov AN, Bichakjian CK, et al. (2009) Primary cilia can both mediate and suppress Hedgehog pathwaydependent tumorigenesis. Nat Med 15: 1055-1061.

12. Emoto K, Masugi Y, Yamazaki K, Effendi K, Tsujikawa H, et al. Presence of primary cilia in cancer cells correlates with prognosis of pancreatic ductal adenocarcinoma. Hum Pathol 45: 817-825.

13. Umberger NL, Caspary T (2015) Ciliary transport regulates PDGF-AA/ alphaalpha signaling via elevated mammalian target of rapamycin signaling and diminished PP2A activity. Mol Biol Cell 26: 350-358.

14. Balmer S, Dussert A, Collu GM, Benitez E, Iomini C, et al. (2015) Components of Intraflagellar Transport Complex A Function Independently of the Cilium to Regulate Canonical Wnt Signaling in Drosophila. Dev Cell 34: 705-718. 